\title{
Transformasi Karakter Anak Berbasis Nilai-nilai Kearifan Lokal Melalui Tarian Tradisional: Pendekatan Bootstrap
}

\author{
Umi Mahmudah $^{1}$, Syifa Ulwiyah ${ }^{2}$, Siti Fatimah ${ }^{3}$, Abdul Hamid $^{4}$ \\ 1,2,4 Institut Agama Islam Negeri Pekalongan, ${ }^{3}$ Institut Agama Islam NU Kebumen \\ umi.mahmudah@iainpekalongan.ac.id
}

\section{Article History \\ received 30/5/2021}

\begin{abstract}
The goal of this study was to look at the impact of traditional dance training on the character development of children in Pekalongan based on local wisdom values. Local wisdom values become an area's identity. These values can be found in a variety of fields, one of which is a traditional dance that can help shape a child's character in a way that is respectful of local culture. This study employs a mixed-method approach, with a focus on quantitative approach. To provide more accurate results, quantitative data analysis was performed using a bootstrap approach to the paired sample $t$-test. The qualitative results, on the other hand, are based on observations and interviews. Thirty children in primary and junior high school participated in traditional dance training. A dance instructor led the training. There are four traditional dances introduced, namely the ampar-ampar pisang, the cublak-cublak suweng, the manuk dadali, and the payung dances. The findings revealed that after taking part in this training, the participants were able to increase their knowledge and awareness of local cultural values. This result is proven by bootstrap analysis which produces a p-value of 0.00. Among the local wisdom-based characters that were formed, namely honesty, not indulging in lust, caring, like to help, teamwork, a sense of nationalism and nationality, tolerance, readiness, prudence, and vigilance. The implication is that traditional dance practice can be used as an alternative strategy to shape the character of children in society who are interested in local culture.
\end{abstract}

Keywords: local wisdom, traditional dance, character

\begin{abstract}
Abstrak
Tujuan penelitian ini adalah menguji efektivitas pelatihan tari tradisional terhadap pengembangan karakter berbasis nilai-nilai kearifan lokal anak-anak di Pekalongan. Nilai-nilai kearifan lokal menjadi identitas suatu daerah. Nilai ini terkandung dalam banyak bidang, salah satunya tarian tradisional yang dapat membentuk karakter anak yang ramah terhadap nilai-nilai kearifan lokal. Penelitian ini menggunakan pendekatan mixed-method dengan menitikberatkan pada pendekatan kuantitatif. Analisis data kuantitatif dilakukan menggunakan pendekatan bootstrap pada paired sample t-test untuk memberikan hasil yang lebih akurat. Sedangkan hasil kualitatif berdasarkan observasi dan wawancara. Sebanyak 30 anak-anak usia sekolah dasar dan sekolah menengah pertama mengikuti pelatihan tari tradisional. Pelatihan dipimpin oleh seorang instruktur tari. Ada empat tarian tradisional yang dikenalkan, yaitu tari ampar-ampar pisang, tari cublak-cublak suweng, tari manuk dadali, dan tari payung. Hasil penelitian menunjukkan bahwa setelah mengikuti pelatihan ini, peserta berhasil meningkatkan pengetahuan dan kesadaran nilai budaya lokal. Hasil ini dibuktikan dengan analisis bootstrap yaitu menghasilkan nilai $p$-value 0,00 . Diantara karakter berbasis kearifan lokal yang terbentuk adalah kejujuran, tidak menuruti hawa nafsu, peduli, suka menolong, kegotongroyongan, rasa nasionalisme dan kebangsaan, toleransi, kesiapan, kehati-hatian, dan kewaspadaan. Implikasinya, praktek tarian tradisional pada anak dapat dijadikan sebagai alternatif strategi untuk membentuk karakter anak-anak yang mencintai budaya lokal yang ada di masyarakat.
\end{abstract}

Kata kunci: kearifan lokal, tari tradisional, karakter 


\section{PENDAHULUAN}

Indonesia merupakan bangsa majemuk yang terdiri dari berbagai suku, agama, ras, dan antar golongan. Maka, ada banyak nilai-nilai sosial budaya yang berkembang di masyarakat Indonesia yang kemudian berkembang dan diturunkan sejak zaman nenek moyang dalam bentuk nilai-nilai kearifan lokal (local wisdom). Maka dari itu, nilai kearifan lokal mungkin tidak sama di beberapa daerah karena sangat dipengaruhi oleh gaya hidup masyarakat setempat. Sayangnya, perkembangan zaman yang dibarengi dengan perkembangan teknologi terkesan menggerus berbagai nilai-nilai kearifan lokal, terutama bagi generasi muda dan anak-anak. Padahal, kearifan lokal merupakan salah satu karakteristik bangsa Indonesia yang dapat dijadikan sebagai identitas bangsa di mata dunia internasional. Kekayaan budaya bangsa yang telah dikenal oleh masyarakat umum seharusnya dijaga dan dilestarikan. Maka dari itu, penanaman karakter berbasis kearifan lokal yang tidak hanya mencakup pengenalan dan pengetahuan akan budaya bangsa namun juga mampu menyerap nilai-nilai moral yang terkandung di dalamnya, seharusnya dilakukan sejak dini, yaitu pada generasi muda sebagai penerus peradaban budaya bangsa. Ihsan menyebutkan bahwa pembentukkan karakter pada anak terutama memahami budaya lokal dapat dilakukan sejak usia dini. Karena pada masa ini guru lebih mudah dalam mengarahkan dan membentuk karakter/moral yang positif (Ihsan, 2019). Pentingnya pembentukan karakter pada usia dini karena anak sangat peka terhadap segala perlakuan yang diterima dan disimpan dalam memorinya. Oleh sebab itu pendekatan berbasis kearifan lokal menjadi langkah yang tepat dalam membentuk dampak positif anak, baik pada nilai-nilai agama dan moral, sosial-emosional, serta kemandirian (Ashar, 2017).

Kementerian Pendidikan dan Kebudayaan Republik Indonesia menyatakan bahwa kearifan lokal (local wisdom) di Indonesia mengajarkan warganya untuk bersikap ramah, kooperatif, santun, mau berkorban, memiliki etos kerja yang baik, saling menghormati, dan toleransi. Menurut Undang-Undang Nomor 32 Tahun 2009 tentang Perlindungan dan Pengelolaan Lingkungan Hidup, kearifan lokal diartikan sebagai nilai-nilai luhur yang diterapkan dalam kehidupan masyarakat untuk menjaga dan mengelola lingkungan secara berkelanjutan (Kementerian Pendidikan dan Kebudayaan, 2016). Adapula yang mengatakan bahwa kearifan lokal adalah bentuk pemahaman dari gagasan setempat yang mempunyai nilai baik sehingga diikuti oleh anggota masyarakat. Selain menjadi gagasan pemikiran, nilai kearifan lokal dapat disebut sebagai adat istiadat, norma, budaya, kepercayaan, rutinitas sehari-hari. Hal ini sangat pekat dengan karakter yang terbentuk di masyarakat, tanpa disadari nilai budaya dalam masyarakat dapat membentuk karakter. Kearifan lokal juga memiliki relasi dengan sosiokultural yang mana salah satunya ada nilai spiritual (Opsantini, 2014).

Kearifan lokal bisa dipahami sebagai perwujudan sebagaimana masyarakat menjalani kehidupan yang mampu bersinergi, baik dengan lingkungan sosial, maupun lingkungan alam. Ada beberapa faktor yang dapat mempengaruhi terbentuknya kearifan lokal suatu daerah, diantaranya adalah kondisi geografis, nilai religi, dan keadaan sosial masyarakat. Kearifan lokal lahir dengan menganut prinsip, nasehat, dan perilaku nenek moyang yang kemudian diturunkan dari generasi ke generasi. Kearifan lokal juga merupakan pengetahuan dasar yang bersumber dari keseimbangan kehidupan manusia dengan alam sekitarnya (Ahmad et al., 2021).

Salah satu bentuk kearifan lokal masyarakat Indonesia adalah seni tari tradisional, yang digunakan untuk mengekspresikan berbagai hal penting yang berkembang di masyarakat sekitar. Seni tradisional adalah bentuk kebudayaan daerah yang mengandung unsur-unsur serta nilai budaya daerah tersebut. Indonesia memiliki banyak tari-tarian tradisional, dimana yang paling populer ada 10 tari tradisional 
diantaranya adalah: 1) tari jaipong yang berasal dari Jawa Barat; 2) tari kecak yang berasal dari Bali; 3) tari remong yang berasal dari Jawa Timur; 4) tari pendet berasal dari Bali; 5) tari zapin berasal dari Riau; 6) tari gambyong berasal dari Jawa; 7) tari yapong berasal dari Betawi; 8) tari leleng berasal dari Kalimantan Timur; 9) tari piring berasal dari Sumatera Barat; 10) tari ratoh jaroe berasal dari Aceh (Retnoningsih, 2017). Tarian tradisional adalah salah satu potensi lokal yang perlu dilestarikan. Kesenian tari merupakan kesenian budaya yang perlu untuk dilestarikan. Hal ini dikarenakan disetiap tarian memiliki makna yang berbeda-beda dan terkandung banyak nilai-nilai moral (Meidikayanti \& Wahyuni, 2017).

Fadilah menyatakan bahwa meskipun belum berjalan dengan baik, namun pengenalan tarian tradisional dapat mengembangkan karakter anak-anak di tingkat Sekolah Dasar, khususnya ketika dititikberatkan pada ranah motoric (Fadilah, 2016). Restian melaporkan bahwa pembentukan karakter anak yang positif sehingga mengakar dalam kehidupan keseharian mereka dapat dibentuk melalui seni tari tradisional. Karena selain belajar berbagai gerakan tarian, penanaman pendidikan karakter juga secara langsung disisipkan pada setiap latihan (Restian, 2020). Diantara pendidikan karakter yang terkandung dalam seni tari tradisional adalah anak-anak terbiasa untuk bekerja secara bersamaan, memiliki empati yang baik, memiliki sikap mandiri dan sopan santun serta suka menolong sesama manusia. Belajar tari tradisional dapat memperkaya pengalaman peserta serta melatih intelektualitas dan akal sehat dengan cara memahami karakter kearifan lokal yang terkandung dalam tari tradisional (Riyaningsih et al., 2018). Pembelajaran tari tradisional dapat memberikan pengaruh positif dalam pembentukan karakter peserta didik dalam bentuk nilai-nilai keagamaan, kejujuran, tanggung jawab, kerjasama, toleransi, kedisiplinan, dan kreativitas.

Tujuan utama penelitian ini adalah menganalisis efektivitas pelatihan seni tari tradisional pada pengembangan karakter berbasis nilai-nilai kearifan lokal pada anakanak di Pekalongan. Hal ini sangat penting karena anak-anak zaman sekarang yang memiliki gaya hidup serba modern cenderung kurang memiliki pengetahuan dan pemahaman akan budaya-budaya lokal yang ada di Indonesia, termasuk seni tari tradisional. Dengan belajar tari tradisional, anak-anak juga secara tidak langsung dapat menyerap berbagai nilai-nilai budaya yang terkandung dalam setiap tari tradisional. Dengan memiliki pemahaman yang lebih baik akan nilai-nilai kearifan lokal, maka anak-anak menjadi aset yang sangat penting dalam hal pelestarian nilai-nilai budaya bangsa dalam rangka menghadapi perkembangan zaman yang semakin maju.

\section{METODE}

Penelitian ini merupakan penelitian mixed-method yang mengkombinasikan pendekatan kualitatif dan kuantitatif (Creswell \& Creswell, 2018). Jenis desain penelitian ini berbentuk explanatory sequential, yang menitikberatkan pada analisis kuantitatif. Penelitian ini dilaksanakan selama 3 bulan yang dimulai pada 1 September 2020 dan berakhir pada 30 November 2020 di desa Rowolaku, Kecamatan Kajen, Kabupaten Pekalongan, Jawa Tengah.

Jenis tari tradisional yang dikenalkan dan dilatihkan ke anak-anak adalah tari ampar-ampar pisang, tari cublak-cublak suweng, tari manuk dadali, dan tari payung. Pelatihan tarian tradisional diikuti oleh 30 anak-anak. Untuk latihan tari cublak-cublak suweng, peserta ada 10 anak yang semua anggotanya perempuan. Sementara itu, pelatihan tarian manuk dadali beranggota 6 anak yang terdiri dari anak-anak perempuan. Kemudian, tari ampar-ampar pisang yang diperagakan oleh 2 laki-laki dan 4 perempuan. Sementara itu, tari payung diperagakan oleh 10 anak.

Instrumen yang digunakan berupa lembar angket dan lembar observasi dengan teknik pengambilan data melalui obervasi dan dokumentasi. Lembar angket digunakan 
untuk mengetahui efektivitas tarian tradisional dalam meningkatkan karakter anak. Sedangkan lembar obervasi digunakan untuk mengetahui gambaran yang lebih detail dalam pelaksanaan tari tardisional. Teknik analisis data statistik menggunakan pendekatan bootstrap dengan hipotesis nol $\left(\mathrm{H}_{0}\right)$ yang digunakan adalah "Tarian tradisional tidak efektif untuk meningkatkan karakter anak-anak berbasis kearifan lokal". Sedangkan hipotesis alternatif $\left(\mathrm{H}_{1}\right)$ adalah "Tarian tradisional efektif untuk meningkatkan karakter anak-anak berbasis kearifan lokal". Hipotesis ini dianalisis menggunakan pendekatan paired sample t-test, yang mana biasa digunakan untuk menguji efektivitas dari suatu perlakuan terhadap suatu objek (U. Mahmudah, 2020). Selain itu, pendekatan bootstrap juga diterapkan pada paired sample t-test untuk mendapatkan hasil estimasi yang lebih baik (U. Mahmudah \& Fatimah, 2021). Metode paired sample t-test konvensional menuntut distribusi data yang normal karena merupakan salah satu statistic parametrik. Sedangkan, bootstrap merupakan pendekatan non-parametrik sehingga tidak memerlukan uji asumsi tersebut (Eck, 2018; Mustakim et al., 2019).

\section{HASIL DAN PEMBAHASAN}

Penelitian ini menggunakan sebanyak 30 responden, yang semuanya anak-anak yang mengikuti pelatihan seni tari tradisional. Terdapat $70,00 \%$ atau 21 responden usia Sekolah Dasar (SD) dan selebihnya, 30,00\% dari responden adalah anak-anak usia Sekolah Menengah Pertama (SMP). Usia paling muda adalah termuda 6 tahun sedangkan usia paling tua 15 tahun. Sehingga rata-rata usia dari mereka adalah 7 tahun. Kriteria responden berdasarkan jenis kelamin terdiri dari 6 anak laki-laki yaitu sebesar 10,00\% dan 27 anak perempuan yaitu sebesar 90,00\%. Dari gambaran responden, diketahui bahwa responden didominasi oleh anak-anak perempuan dan mereka yang masih mengenyam pendidikan Sekolah Dasar.

\section{Pelaksanaan Pelatihan Tari Tradisional}

Penerapan kegiatan seni tari yang terampil pada anak-anak di desa Rowolaku yang pertama yaitu memperkenalkan tarian-tarian kepada anak-anak seperti pengenalan gerakan tubuh serta pengenalan lagu-lagu daerah yang mengiringi tarian tersebut. Kegiatan melatih gerakan tari dilaksanakan setiap hari senin sampai kamis. Pada hari jumat, anak-anak dilatih membuat properti tari benda yang akan digunakan untuk mendukung ungkapan suatu gerakan. Selanjutnya, setiap hari sabtu anak-anak belajar empat tarian tradisional, yaitu tari cublek-cublek suweng, tari manuk dadali, tari ampar-ampar pisang, dan tari payung.

Gambar 1 adalah proses kegiatan pelaksanaan mengenal tarian tardisional. Kegiatan dimulai dengan mengenalkan terlebih dahulu gerakan-gerakan tubuh tarian tardisional. Selanjutnya dilakukan pelatihan tarian tradisional. Kegiatan puncak dari pengenalan tarian tradisional ini adalah pentas seni tari.

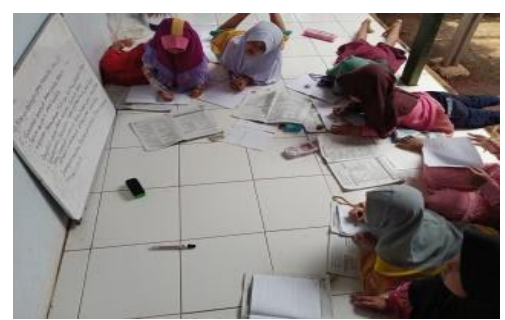

Pengenalan gerakan tubuh tarian tradisional

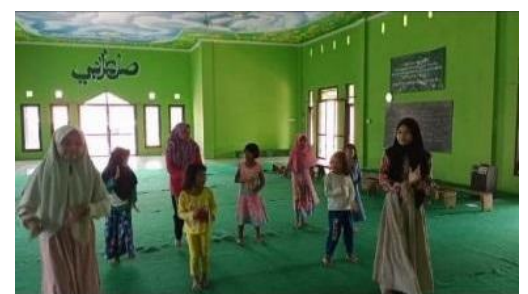

Pelatihan tarian ampar-ampar pisang 


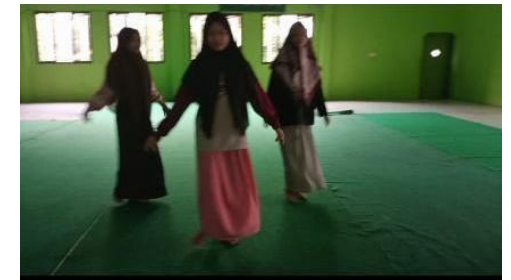

Pelatihan tarian manuk dadali

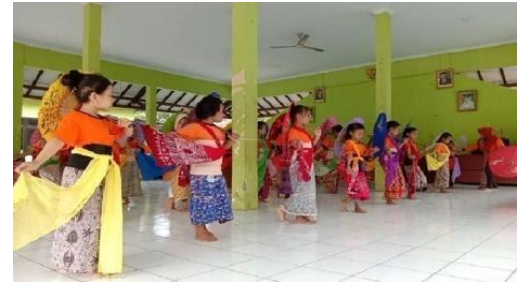

Pentas seni tari tradisional

\section{Gambar 1. Pembelajaran tari tradisional}

Tarian-tarian pada gambar 1 mempunyai makna toleransi, yaitu sikap saling menghargai, peduli, tolong menolong dan kegotongroyongan dalam perbedaan, yang dapat menumbuhkan kesemangatan dalam cinta tanah air sejak usia dini. Melalui gerakan tarian anak dapat mengoptimalkan segala potensi yang ada pada tubuh manusia seperti potensi pendengaran, penglihatan, kepekaan rasa, kepekaan berimajinasi, dan kemampuan mengembangkan daya pikirnya (Budiman \& Karyati, 2021). Melalui tarian, anak-anak akan terbiasa dalam menerapkan karakter positif dalam kehidupan sehari-hari.

\section{Efektivitas Pelatihan Tari Tradisional dalam meningkatkan karakter anak berbasis kearifan lokal}

Uji efektivitas pelatihan tari tradisional dalam penelitian ini menggunakan pendekatan Bootstrap. Sebelum menganalisis efektivitas, perlu dilakukan uji prasyarat yaitu dengan uji normalitas data. Tabel 1 mengilustrasikan uji normalitas data yang digunakan dalam penelitian ini menggunakan uji Kolmogorov-Smirnov.

Tabel 1. Uji Normalitas Data

\begin{tabular}{llrr}
\hline & & Before & \multicolumn{1}{c}{ After } \\
\hline $\mathrm{N}$ & & 30 & 30 \\
Normal & Mean & 77,70 & 80,73 \\
Parameters & Std. Deviation & 3,914 & 4,085 \\
& & & \\
Most Extreme & Absolute & 0,197 & 0,195 \\
Differences & Positive & 0,157 & 0,138 \\
& Negative & $-0,197$ & $-0,195$ \\
Test Statistic & & 0,197 & 0,195 \\
Asymp. Sig. (2-tailed) & 0,002 & 0,005 \\
\hline
\end{tabular}

Berdasarkan tabel 1 terlihat bahwa hasil uji normalitas menyatakan bahwa data yang digunakan dalam penelitian tidak berdistribusi secara normal. Hal ini berdasarkan pada nilai asymptotic significance ( $p$-value), dimana data sebelum dan sesudah dilaksanakan pelatihan tarian tradisional secara berurutan memberikan angka 0,002 dan 0,005. kedua angka tersebut adalah lebih kecil dari 0,05. Dengan demikian, metode paired sample t-test konvensional tidak tepat digunakan untuk menganalisis efektivitas pelatihan seni tari tradisional untuk meningkatkan karakter anak-anak berbasis kearifan lokal. Oleh sebab itu, diperlukan pendekatan non-parametrik untuk menganalisis data penelitian yang tidak terdistribusi secara normal. Sehingga dalam analisis ini menggunakan pendekatan hybrid dengan mengkombinasikan pendekatan bootstrap dan paired sample t-test. Tabel 2 adalah deskripsi statistik sampel 
berdasarkan pendekatan bootstrap pada data sampel berpasangan (paired sample $t$ test), yaitu data sebelum pelatihan dan data sesudah pelatihan. Jumlah replikasi bootstrap yang digunakan dalam penelitian ini adalah $B=1000$.

Tabel 2. Deskripsi Statistik Sampel Bootstrap

\begin{tabular}{|c|c|c|c|c|c|c|}
\hline & & & \multirow[t]{2}{*}{ Bias } & \multirow[t]{2}{*}{ Std. Error } & \multicolumn{2}{|c|}{$\begin{array}{c}\text { 95\% Confidence } \\
\text { Interval }\end{array}$} \\
\hline & & & & & Lower & Upper \\
\hline \multirow[t]{4}{*}{ Before } & Mean & 77,70 & 0,03 & 0,71 & 76,30 & 79,10 \\
\hline & $\mathrm{N}$ & 30 & & & & \\
\hline & Std. Deviation & 3,91 & $-0,09$ & 0,42 & 2,97 & 4,64 \\
\hline & Std. Error Mean & 0,72 & & & & \\
\hline \multirow[t]{4}{*}{ After } & Mean & 80,73 & $-0,01$ & 0,71 & 79,33 & 82,13 \\
\hline & $\mathrm{N}$ & 30 & & & & \\
\hline & Std. Deviation & 4,08 & $-0,13$ & 0,66 & 2,68 & 5,19 \\
\hline & Std. Error Mean & 0,75 & & & & \\
\hline
\end{tabular}

Tabel 2 menunjukkan hasil statistik deskriptif untuk dua kondisi, yaitu data sebelum dan sesudah pelatihan tari tradisional. Rata-rata skor pada data sebelum adalah sebesar 77,70 sedangkan rata-rata skor data sesudah pelatihan adalah 80,73. Berdasarkan nilai standar deviasi, juga terlihat bahwa skor pada kedua kondisi tersebar dengan cara yang sama.

Kemudian, tabel 3 menggambarkan hasil analisis pada efektivitas pelaksanaan pelatihan tarian tradisional pada anak-anak menggunakan pendekatan bootstrap pada paired sample $t$-test.

Tabel 3. Bootstrap pada Paired Sample t-test

\begin{tabular}{|c|c|c|c|c|c|c|c|c|c|}
\hline & \multirow{3}{*}{$\begin{array}{c}\text { Mea } \\
\mathrm{n}\end{array}$} & \multirow{3}{*}{$\begin{array}{l}\text { Std. } \\
\text { Dev }\end{array}$} & \multirow{3}{*}{$t$} & \multirow{3}{*}{$d f$} & \multicolumn{5}{|c|}{ Bootstrap } \\
\hline & & & & & \multirow[t]{2}{*}{ Bias } & \multirow[t]{2}{*}{$\begin{array}{l}\text { Std. } \\
\text { Error }\end{array}$} & \multirow[t]{2}{*}{$\begin{array}{l}\text { Sig. (2- } \\
\text { tailed) }\end{array}$} & \multicolumn{2}{|c|}{$\begin{array}{c}\text { 95\% Confidence } \\
\text { Interval }\end{array}$} \\
\hline & & & & & & & & Lower & Upper \\
\hline $\begin{array}{l}\text { Before } \\
\text { - After }\end{array}$ & $-3,03$ & 3,67 & $-4,52$ & 29 & 0,03 & 0,64 & 0,00 & $-4,33$ & $-1,83$ \\
\hline
\end{tabular}

Tabel 3 adalah tabel paling penting, karena berisi uji statistik inferensial. Tabel ini dijadikan landasan utama dalam memutuskan apakah ada perbedaan yang signifikan secara statistik antara kondisi tersebut, dan apakah hipotesis nol dapat ditolak untuk mendukung hipotesis penelitian.

Hasil analisis menggunakan software SPSS versi 24 memberikan beberapa hasil berikut. Nilai $t_{\text {hitung }}$ adalah sebesar $-4,525$ dengan derajat kebebasan (degree of freedom) sebanyak 29. Kemudian, diperoleh nilai signifikansi ( $p$-value) menggunakan uji hipotesis dua arah (2-tailed) sebesar 0,00. Dengan menggunakan derajat kebebasan $(d f)=29$ dan level signifikansi $5 \%$ maka nilai tabel pada uji hipotesis dua arah menghasilkan nilai sebesar 2,04. Penting untuk diinformasikan bahwa pada uji $t$ menggunakan pendekatan paired sample, nilai thitung yang negatif (dalam penelitian ini $t_{\text {hitung }}=-4,525$ ) disebabkan karena skor sebelum dilakukan pelatihan adalah lebih rendah dibandingkan dengan skor setelah dilakukan pelatihan tari tradisional. Maka, 
dalam konteks seperti ini nilai thitung yang negatif tersebut dapat memiliki makna yang positif, sehingga dapat juga ditulis dengan thitung $=4,525$.

Lebih lanjut, tabel 3 juga mengindikasikan bahwa pendekatan bootstrap adalah tepat diterapkan untuk menganalisis data. Ini terlihat dari kecilnya nilai bias estimasi, yaitu 0,03. Nilai ini merepresentasikan selisih atau perbedaan antara nilai yang diharapkan dari penaksir dan nilai sebenarnya. Selain itu, hasil analisis bootstrap juga memberikan standar error yang sangat kecil, yaitu 0,64. Standar error yang kecil mengindikasikan akurasi estimasi yang lebih baik. Hasil ini konsisten dengan penelitian-penelitian sebelumnya yang menyatakan bahwa pendekatan non-parametrik bootstrap mampu memberikan hasil estimasi dengan akurasi yang lebih baik dibandingkan dengan metode statistik tradisional (Chernick \& LaBudde, 2014; Eck, 2018; U. Mahmudah \& Fatimah, 2021). Akurasi hasil yang sangat signifikan ketika menggunakan pendekatan bootstrap (Watagoda \& Olive, 2019). Chernick \& LaBudde juga memberikan laporan serupa, dimana bootstrap mengarah pada hasil estimasi yang lebih baik (Chernick \& LaBudde, 2014).

Dari hasil tersebut, maka keputusan akhir analisis adalah menolak Hipotesis nol $\left(\mathrm{H}_{0}\right)$. Maka, hasil penelitian mengindikasikan pernyataan "Tarian tradisional tidak efektif untuk meningkatkan karakter anak-anak berbasis kearifan lokal" adalah ditolak. Konsekuensinya, kesimpulan akhir penelitian ini mengarah pada "Tarian tradisional efektif untuk meningkatkan karakter anak-anak berbasis kearifan lokal". Hasil ini juga berimplikasi bahwa tarian tradisional berpengaruh secara positif dalam meningkatkan karakter anak-anak berbasis kearifan lokal. Selanjutnya, berdasarkan tabel 3 juga diketahui nilai mean paired differences sebesar -3,03, yang mana mengindikasikan selisih skor antara sebelum dan sesudah dilaksanakan pelatihan tari tradisional. Dari tabel tersebut juga terlihat dengan jelas bahwa nilai tersebut berada pada interval $-4,33$ sampai $-1,83$ sebagai angka-angka confidence interval yang hasil analisis. Dengan kata lain, pelatihan tari tradisional dinyatakan efektif dalam peningkatan karakter anak berbasis nilai-nilai kearifan lokal.

Hasil penelitian ini tidak kontradiksi dengan penelitian-penelitian sebelumnya, yang mana mayoritas melaporkan keselarasan antara kesenian tradisional dan peningkatan karakter anak. Seni tradisional dalam bentuk karya tatah sungging menggambarkan karakteristik tradisional masyarakat melalui nilai-nilai sejarah dan filosofis yang dapat membentuk karakter anak-anak sejak dini (Tanto et al., 2019). Kearifan lokal Indonesia yang tercermin dalam nilai-nilai tradisional antara lain berupa karakter yang penuh dengan kesabaran, ketekunan, mandiri, disiplin yang tinggi, dan kerja sama serta gotong royong. Setiowati juga melaporkan hasil yang hamper sama, dimana lagu tradisional berjudul "tokecang" yang identic dengan budaya di provinsi Jawa Barat dapat membentuk pribadi dan karakter yang kuat pada anak-anak (Setiowati, 2020). Meskipun lagu tersebut terkesan sangat sederhana, namun memberikan makna yang luar biasa dalam bentuk kasih sayang dan kepedulian sosial dalam bermasyarakat. Tidak hanya itu, karakter tersebut juga ditujukan bukan hanya kepada sesama manusia tapi juga pada objek, hewan, dan makhluk sekitar kita. Lebih lanjut, Andriani melaporkan bahwa permainan-permainan tradisional mampu membantu pembentukan karakter anak sejak usia dini (Andriani, 2012).

Hasil observasi selama kegiatan pelatihan tari tradisional yang dilakukan secara berkesinambungan selama tiga bulan menghasilkan temuan-temuan penting berikut. Pada pelatihan tarian cublak-cublak suweng, lagu cublak-cublak suweng juga mengiringi setiap gerak dan langkah yang diperagakan oleh anak-anak. Dalam pelatihan, anak-anak juga dilatih macam-macam gerakan, dimulai dari gerakangerakan tangan terlebih dahulu yaitu gerak ngithing, ngrayung, kebyak, dan ulap-ulap. Selanjutnya, gerakan kedua adalah gerakan kepala yang terdiri dari gerak gebes, banyak slulup, lenggut, dan tolehan. Gerakan yang ketiga adalah gerakan dasar mata, dimana anak-anak dilatih gerakan yang dinamakan dengan nyeledet. Selanjutnya, 
gerakan yang keempat berupa gerakan dasar badan, yang meliputi hoyog, ogeg, dan mendhak. Yang terakhir adalah gerakan kaki, yang mencakup beberapa gerakan kaki yaitu trecet, jengkeng, nggroda, dan enjeran. Dari hasil pengamatan, diketahui bahwa pada latihan tarian cublak-cublak suweng, terdapat 1 anak yang belum bisa menguasai semua gerakan secara sempurna. Selain itu, gerakan pada tubuhnya juga belum lentur sesuai dengan keinginan pelatih. Manakala, 7 anak sudah mampu memperagakan tarian tersebut dengan gerakan yang lincah dan lentur.

Kemudian pada kelompok kedua dengan tarian payung yang beranggota 11 anak perempuan yang rata-rata umurnya 6 tahun sampai 8 tahun, hasil observasi mengindikasikan bahwa para peserta rata-rata sudah lincah dan lentur dalam gerakan tarian payung. Dari hasil wawancara juga diketahui bahwa ada beberapa anak yang ternyata sudah pernah belajar tari payung. Hampir semua anak mengatakan menyukai gerakan-gerakan pada tarian payung sehingga mereka dengan mudah bisa menguasai gerakan dan sesuai yang diinginkan pelatih.

Secara umum, pelatihan tarian tradisional lainnya mengindikasikan hal yang sama, yaitu anak-anak sangat antusias dan berperan aktif dalam setiap kegiatan pelatihan sehingga sangat memudahkan tugas pelatih. Semangat mereka yang berapi-api menyebabkan mereka dengan cepat dapat mempelajari dan memperagakan setiap gerakan dengan baik.

Hasil analisis berdasarkan observasi dan wawancara terhadap anak-anak juga mengindikasikan bahwa anak-anak sangat antusias mengikuti kegiatan menari tradisional. Hal ini terlihat dari sikap mereka yang selalu aktif dan semangat dalam mengikuti setiap kegiatan yang diberikan oleh pelatih, seperti datang tepat waktu. Adapun pelatihan tarian tradisional dijadwalkan setiap Sabtu dan Minggu pukul 08.00 WIB sampai dengan selesai. Hampir semua anak diketahui hadir tepat waktu. Meskipun kadangkala ada beberapa anak yang terlambat, tapi tidak pernah melebihi pukul 08.15 WIB. Sehingga, semua kegiatan pelatihan dapat dilaksanakan dengan tertib dan sesuai perencanaan pelatih.

Kegiatan pelatihan tari tradisional sangat disenangi oleh anak-anak karena bisa menambah wawasan ilmu dan dapat mengetahui budaya-budaya tari tradisional dan dapat melatih percaya diri anak, selain itu juga bisa menambah bakat pada anak-anak yang ada di desa rowolaku. Dalam tarian yang diperagakan dapat menjadi sebuah media hiburan dan menghilangkan rasa bosan pada anak-anak. Dari hasil wawancara yang peneliti lakukan menginformasikan anak-anak rata-rata sudah bisa memperagakan gerakan pada tubuh dengan baik dan benar walaupun ada salah satu anak yang belum menguasai merasa kesulitan dalam gerakan-gerakan yang ada pada tarian gerakan tersebut. Anak-anak mengikuti pelatihan tari dengan semangat.

Seni tari tradisional yang diwariskan secara turun temurun sejak zaman dahulu yang dilestarikan menjadi bagian budaya daerah. Dalam tari tradisional terdapat filosofi, simbol, dan unsur religius. Tarian tradisional biasanya tidak memiliki perubahan cukup besar, baik dari segi irama dan pengiring, formasi gerakan. Tari tradisional dibagi menjadi dua kategori yaitu tari tradisional klasik merupakan tarian tarian tradisional yang dikembangkan oleh bangsawan istana atau keraton. Sedangkan tari tradisional kerakyatan adalah yang dikembangkan oleh kalangan rakyat biasa. Tarian ini memiliki gerakan yang tidak terlalu baku dan bisa dikembangkan. Baik ragam gerakan maupun kostum yang digunakan sederhana (Restian, 2016, 2020). Adanya pengaruh apresiasi terhadap seni tari anak-anak dapat mengenal jati dirinya sekaligus memahami identitas bangsanya. Sehingga anak-anak lebih bangga menghargai, mengenal, serta menjaga budaya sebagai jati diri bangsanya. Bentuk kebanggaan siswa ini merupakan suatu dorongan seseorang dalam bertindak (Retnoningsih, 2017). Selain sebagai edukasi adanya dorongan akan menumbuhkan sikap rasa ingin tahu siswa untuk menggali lebih tentang suatu hal yang menarik untuk dipelajari sehingga pada akhirnya menumbuhkan rasa kebangaan serta kecintaan terhadap daerah. 
Dengan demikian, konsep pembelajaran seni tari adalah sebagai sarana atau media pendidikan, seni tari berkaitan dengan perkembangan karakter kebudayaan yang bersifat abstrak bagi jiwa kepribadian manusia (Retnoningsih, 2017).

Nilai kearifan lokal terkandung dalam berbagai bidang, salah satunya adalah seni tari tradisional yang dapat digunakan sebagai sarana untuk mengekspresikan keindahan. Seni batik sangat identik dengan Pekalongan, maka tidaklah mengherankan jika ada seni yang dinamakan dengan seni tari batik jlamprang, yang merupakan tari ciptaan manusia untuk mengekspresikan keindahan. Tari ini mengandung arti proses membatik yang ada dalam masyarakat Pekalongan sebagai salah satu budaya lokal yang dilestarikan secara turun temurun sejak zaman nenek moyang. Gerakan yang ditampilkan dan ditarikan dalam tari batik jlamprang bersifat dinamis. Tari sendiri memiliki simbol yang tidak terlepas dari beberapa aspek yang dapat dilihat secara terperinci, yaitu gerak tari, iringan tari, pola lantai, tata pakaian, dan tata rias, dan properti tari (Rosala, 2017).

Nilai-nilai kearifan lokal masyarakat Pekalongan juga mencakup nilai-nilai religious, yang mana juga terkandung dalam berbagai seni tari tradisional Indonesia (Hidayat \& Haryati, 2019). Pekalongan terkenal dengan kota santri yang cenderung religius. Maka, nilai-nilai kearifan lokal yang sangat terkenal adalah makam Sapuro sebagai wisata religious (Nisrina et al., 2021). Nilai-nilai yang terkandung pada tari ampar-ampar pisang adalah pesan moral kepada anak supaya anak tidak mencuri pisang yang masih dalam proses penjemuran, melatih kejujuran yang dilatih sejak usia anak-anak. Nilai-nilai yang ada pada tari cublak-cublak suweng adalah untuk mencari harta janganlah menuruti hawa nafsu tetapi semuanya kembali kehati yang nurani akan lebih bersih. Tidak dipengaruhi hawa nafsu dengan hati yang nurani akan mendapatkan kebahagiaan, termasuk adalah nilai moral yang berorientasi terhadap ajakan moral merupakan nasihat atau amanat mengenai benar tidaknya sikap manusia (Ariesta, 2019).

Kemudian, nilai-nilai kearifan lokal yang terkait dengan rasa nasionalisme dan kebangsaan juga terkandung dalam berbagai gerakan tari tradisional. Tari manuk dadali memiliki nilai-nilai keindahan yang sangat erat hubungannya dengan nasionalisme yang tinggi dan memiliki motivasi untuk menggali nilai-nilai luhur yang terkandung di dalamnya yang mengajarkan Bhineka Tunggal Ika (S. R. Mahmudah, 2019). Nilai-nilai yang terdapat dalam seni tari payung dalam setiap gerakan menggambarkan kesiapan, kehati-hatian, dan kewaspadaan dalam suatu perjalanan tentu tidak akan selalu lurus dan aman jalan yang melewati karena akan selalu ada rintangan-rintangan yang siap menghadang. Karena itu, perlu siap dalam menghadapi rintangan. Melalui pengkajian yang struktur tari payung tergambar makna secara singkat dalam perjalanan ada tantangan alam yang dihadapi maka payung dipakai sebagai lambang tempat pelindung hujan dan panas. Dalam perjalanan hidup pada saat menghadapi tantangan harus berhati-hati dan kewaspadaan dan berserah diri kepada Allah dan mohon perlindungan.

\section{SIMPULAN}

Kearifan lokal adalah suatu pemikiran yang ada dalam kehidupan bermasyarakat, tumbuh kembangnya secara terus menerus melalui kesadaran masyarakat dari yang sakral sampai kehidupan sehari-hari. Seperti di bidang religius tradisi maulid terdapat nilai kearifan lokal berupa nilai religius. Penanaman karakter anak berbasis nilai-nilai kearifan seharusnya dilakukan sedini mungkin. Salah satu strategi yang dapat digunakan adalah dengan mengenalkan berbagai tarian tradisional yang menjadi karakteristik budaya Indonesia. Seni tari tradisional yang diwariskan secara turun temurun sejak zaman dahulu yang dilestarikan menjadi bagian budaya daerah. Dalam tari tradisional terdapat filosofi, simbol, dan unsur religius. Dalam 
rangka melestarikan nilai-nilai kearifan lokal sekaligus pembentukan karakter anak yang ramah akan budaya lokal, penelitian ini menganalisis beberapa jenis tari tradisional yang kemudian dikenalkan pada anak-anak desa Rowolaku. Ada empat tari tradisional yang bukan hanya dikenalkan namun anak-anak juga diberikan pelatihan selama tiga bulan sehingga mereka mampu menguasai gerakan beserta pesan moral yang terkandung di dalam setiap gerakannya.

Hasil analisis mengindikasikan bahwa belajar seni tari tradisional dapat meningkatkan karakter anak yang berlandaskan nilai-nilai kearifan lokal masyarakat. dengan memahami dan menyelami nilai-nilai yang terkandung dalam setiap gerakan tari, anak-anak semakin memahami akan pentingnya budaya bangsa yang seharusnya dijaga dan dilestarikan. Kemudian, dalam tarian-tarian tradisional yang dikenalkan pada anak-anak mempunyai nilai kearifan lokal tersendiri. Nilai-nilai yang terkandung pada tari ampar-ampar pisang adalah pesan moral kepada anak supaya anak tidak mencuri pisang yang masih dalam proses penjemuran, melatih kejujuran yang dilatih sejak usia anak-anak. Nilai-nilai yang ada pada tari cublak-cublak suweng adalah untuk mencari harta janganlah menuruti hawa nafsu tetapi semuanya kembali kehati yang nurani akan lebih bersih. Tidak dipengaruhi hawa nafsu dengan hati yang nurani akan mendapatkan kebahagiaan, termasuk adalah nilai moral yang berorientasi terhadap ajakan moral merupakan nasihat atau amanat mengenai benar tidaknya sikap manusia. Selain itu, rasa nasionalisme dan kebangsaan juga merupakan kearifan lokal yang terkandung dalam tarian manuk dadali. Sedangkan tari payung mengajarkan kesiapan, kehati-hatian, dan kewaspadaan. Kemudian, nilai moral yang terbentuk juga mnecakup toleransi, saling menghargai dalam perbedaan, sikap peduli, tolong menolong, dan kegotongroyongan.

\section{DAFTAR PUSTAKA}

Ahmad, M., Muniroh, S. M., \& Mahmudah, U. (2021). Preserving Local Values in Indonesia: Muslim Student, Moderate Religious, and Local Wisdom. Islamic Studies Journal for Social Transformation, 59-76.

Andriani, T. (2012). Permainan tradisional dalam membentuk karakter anak usia dini. Sosial Budaya, 9(1), 121-136.

Ariesta, F. W. (2019). Nilai Moral dalam Lirik Dolanan Cublak-Cublak Suweng. Jurnal IImu Budaya, 7(2), 188-192.

Ashar, E. R. (2017). Pembentukan Karakter Berbasis Kearifan Lokal pada Anak Usia TK. QAWWAM, 11(2), 121-132.

Budiman, A., \& Karyati, D. (2021). Membentuk Karakter Kreatif: Bergerak Melalui Stimulus Permainan Tradisional. Jurnal PGSD: Jurnal IImiah Pendidikan Guru Sekolah Dasar, 14(1), 1-11.

Chernick, M. R., \& LaBudde, R. A. (2014). An introduction to bootstrap methods with applications to $R$. John Wiley \& Sons.

Creswell, J. W., \& Creswell, D. J. (2018). Research design: Qualitative, quantitative, and mixed methods approaches. United Kingdom, UK. SAGE Publications, Inc.

Eck, D. J. (2018). Bootstrapping for multivariate linear regression models. Statistics \& Probability Letters, 134, 141-149. https://doi.org/10.1016/j.spl.2017.11.001

Fadilah, N. (2016). Pelaksanaan Pembelajaran Ekstrakurikuler Seni Tari Tradisional dalam Membentuk Karakter pada Siswa Kelas Tinggi di SDN Tambakaji 01 Semarang. Universitas Negeri Semarang.

Hidayat, A. G., \& Haryati, T. (2019). Peran Guru Profesional dalam Membina Karakter Religius Peserta Didik Berbasis Nilai Kearifan Lokal (Maja Labo Dahu) Sekolah Dasar Negeri Sila Di Kecamatan Bolo Kabupaten Bima. Jurnal Pendidikan Ips, 9(1), 15-28. 
Ihsan, B. (2019). Peran Pembelajaran Budaya Lokal Dalam Pembentukan Karakter Siswa Madrasah Ibtidaiyah (MI). MIDA: Jurnal Pendidikan Dasar Islam, 2(2), 1-8.

Kementerian Pendidikan dan Kebudayaan. (2016). Analisis Kearifan Lokal Ditinjau dari Keragaman Budaya. Kemendikbud RI.

Mahmudah, S. R. (2019). Cultivating the spirit of nationalism through the song 'Manuk Dadali.' In 21st Century Innovation in Music Education (pp. 266-270). Routledge.

Mahmudah, U. (2020). Metode Statistika: Step by Step. Penerbit NEM.

Mahmudah, U., \& Fatimah, S. (2021). Bootstrap Approach for Analyzing the Influence of Interpersonal Communication Skills on Science Performances. International Journal of Social Sciences \& Educational Studies, 8(1), 137-148. https://doi.org/10.23918/ijsses.v8i1p137.

Meidikayanti, W., \& Wahyuni, C. U. (2017). Hubungan dukungan keluarga dengan kualitas hidup Diabetes melitus tipe 2 di puskesmas pademawu. Jurnal Berkala Epidemiologi, 5(2), 240-252.

Mustakim, Z., Chamdani, M., \& Mahmudah, U. (2019). Comparison of efficiency school performance between natural and social sciences: a bootstrapping data envelopment analysis. Jurnal Cakrawala Pendidikan, 38(2), 281-291. https://doi.org/10.21831/cp.v38i2.22837

Nisrina, H., Agustin, D. S. R., \& Mahmudah, U. (2021). Etnomatematika: Analisis Problem Solving Pada Mata Kuliah Program Linier Berbasis Kearifan Lokal. JMPM: Jurnal Matematika Dan Pendidikan Matematika, 6(1), 72-80.

Opsantini, R. D. (2014). Nilai-Nilai Islami dalam Pertunjukan Tari Sufi pada Grup "Kesenian Sufi Multikultur" Kota Pekalongan. Jurnal Seni Tari, 3(1).

Restian, A. (2016). Pelatihan Guru Seni Tari Tradisional SD Muhammadiyah 8 Dau Malang. Research Report, 315-321.

Restian, A. (2020). Analisis Pembelajaran Tari Tradisional Dalam Pendidikan Karakter Siswa Sekolah Dasar. Sekolah Dasar: Kajian Teori Dan Praktik Pendidikan, 29(2), 119-127.

Retnoningsih, D. A. (2017). Eksistensi Konsep Seni Tari Tradisional Terhadap Pebentukan Karakter Siswa Sekolah Dasar. DIALEKTIKA Jurnal Pemikiran Dan Penelitian Pendidikan Dasar, 7(1), 20-29.

Riyaningsih, E., Maryono, M., \& Harini, H. (2018). Establishment of learners' character through learning traditional dance in senior high school. Harmonia: Journal of Arts Research and Education, 18(1), 13-27.

Rosala, D. (2017). Pembelajaran seni budaya berbasis kearifan lokal dalam upaya membangun pendidikan karakter siswa di sekolah dasar. Ritme, 2(1), 16-25.

Setiowati, S. P. (2020). Pembentukan Karakter Anak Pada Lagu Tokecang, Jawa Barat. Jurnal Ilmu Budaya, 8(1), 172-177.

Tanto, O. D., Hapidin, H., \& Supena, A. (2019). Penanaman Karakter Anak Usia Dini dalam Kesenian Tradisional Tatah Sungging. Jurnal Obsesi: Jurnal Pendidikan Anak Usia Dini, 3(2), 337-345.

Watagoda, P. L. C. R., \& Olive, D. J. (2019). Bootstrapping multiple linear regression after variable selection. Statistical Papers, 1-20. https://doi.org/10.1007/s00362019-01108-9 